\section{Nauplius}

The Journal OF The

Brazilian Crustacean Society

e-ISSN 2358-2936

www.scielo.br/nau www.crustacea.org.br

\title{
Grooming behaviors and gill fouling in the commercially important blue crab (Callinectes sapidus) and stone crab (Menippe mercenaria)
}

\author{
Jen L. Wortham ${ }^{1}$ iD orcid.org/0000-0002-4890-5410 \\ Stephanie Pascual ${ }^{1}$ \\ 1 College of Natural and Health Sciences, University of Tampa, 401 West Kennedy \\ Blvd, Tampa, FL, 33606, USA \\ ZOOBANK http://zoobank.org/urn:lsid:zoobank.org:pub:BB965881-F248-4121- \\ 8DCA-26F874E0F12A
}

\section{Abstract}

Grooming behaviors reduce fouling of body regions. In decapods, grooming time budgets, body regions groomed, and grooming appendages are known in several species; however, little data exists on brachyuran crabs. In this study, grooming behaviors of two commercially important crabs were documented (blue crabs: Callinectes sapidus Rathbun, 1896; stone crabs: Menippe mercenaria Say, 1818). These crabs are harvested by fishermen and knowing their grooming behaviors is valuable, as clean crabs are preferred by consumers and the stone crab fishery consequence of removing one cheliped to grooming behaviors is unknown. Crabs were observed individually and agonistically to determine how grooming behaviors vary in the presence of another conspecific. Both species frequently use their maxillipeds and groom, with the gills being cleaned by epipods. Respiratory and sensory structures were groomed frequently in both species. Removal of a grooming appendage resulted in higher fouling levels in the gills, indicating that grooming behaviors do remove fouling. Overall, stone crabs had a larger individual time budget for grooming, but agonistic grooming time budgets were similar. Stone crab chelipeds are used in grooming, especially cleaning the other cheliped. The chelipeds are not the main grooming appendage; however, implications of losing one cheliped may have large impacts.

\section{KEY WORDS}

Maxillipeds, walking legs, pereiopods, cleaning, SEM.

CORRESPONDING AUTHOR Jen L. Wortham

jwortham@ut.edu

SUBMITTED 19 April 2017

ACCEPTED 20 August 2017

PUBLISHED 26 October 2017

DOI $10.1590 / 2358-2936 e 2017028$

\section{INTRODUCTION}

Grooming is a behavior, similar to cleaning, that removes fouling on the body (Spruiit et al., 1992). Numerous animal groups groom their bodies, ranging from birds (Clayton and Cotgreave, 1994), cats (Eckstein and Hart, 2000), primates (De Waal, 1997), and crustaceans (Bauer, 1981). While 
grooming structures (i.e. beaks in birds, tongues in cats, fingers in primates, and chelipeds in crustaceans) vary between these taxa, the result of removing different types of fouling remains similar and results in a healthy body. The body regions groomed can also vary depending on taxa; however, many grooming actions are directed at respiratory and sensory structures (i.e. for gas exchange, smelling, vision, chemosensory, and mechanosensory). For example, primates frequently groom their ears, hairs, and facial regions (Hutchins and Barash, 1976), while crustaceans often groom their antennae, eyes, and gills (Bauer, 1989).

While grooming is important to individuals, this action is a secondary behavior and is likely reduced when primary behaviors are present (Bauer, 1989; VanMaurik and Wortham, 2014). When primary activities are present, energies and time directed toward grooming should decrease (Bauer, 1989; 2013). However, in an individual's time budget for the 24$\mathrm{hr}$ period, grooming must be accounted for and is likely related to the abundance of primary behaviors and quality of the environment (Holmquist, 1985). In crustaceans, the grooming time budget is lower when primary behaviors are present (20\% compared to $1 \%$; Jedlicka and Wortham, 2014; VanMaurik and Wortham, 2014).

In crustaceans, most grooming behavioral studies have been conducted on shrimps (Bauer, 1977; 1978; 1989; 2013; Felgenhauer and Schram, 1978; 1979). Shrimps usually use their third maxillipeds and chelate walking legs as the main grooming appendages (Bauer, 1981; VanMaurik and Wortham, 2014). Most grooming in shrimps is focused on their respiratory organs, sensory structures, and jointed articulations of all appendages (Bauer, 1977; 1978; 1981; 1989; 1999). These grooming actions are performed by setae on grooming appendages and these setae assist in scraping, brushing, and picking the body and removing fouling (Wortham et al., 2014). The exoskeleton of crustaceans is a target for fouling with common fouling materials being sediment, bacteria, and epibiont growth (Bauer, 2004) and fouling organisms can add weight, limit mobility, and limit the function of organs (Ward, 2012).

While all of these grooming studies have been done on shrimps (mostly Caridea), none have been conducted on a species that is commercially harvested in a natural saltwater fishery (not aquaculture). In addition, little detailed grooming information exists for crabs, with only brief mentions in literature (Bauer, 1981; Martin and Felgenhauer, 1986; Pohle, 1989; Sallem et al., 2007; Jedlicka and Wortham, 2014) and no detailed study exists on the grooming behaviors of brachyuran crabs. Because crab morphologies are different from shrimps, grooming behaviors in crabs are likely to be different. Understanding differences and similarities in grooming behaviors between shrimps and crabs can help researchers better understand how behaviors are conserved between taxonomic groups (Bauer, 1981; Martin and Felgenhauer, 1986). Because commercially important species must be healthy to survive in a fishery, understanding grooming pressures and grooming time budgets for these species is critical.

Blue crabs (Callinectes sapidus Rathbun, 1896) and stone crabs (Menippe mercenaria Say, 1818) are commercially harvested in open waters in the Gulf of Mexico and Atlantic Ocean. Both crab species are economically important, recreationally and commercially; stone crabs are even caught accidently in the blue crab fishery (Bert, 1992). Per year, these fisheries can yield over $\$ 25$ million (blue crabs; Guillory et al., 2001) and 2.6 million pounds (stone crabs: Puglisi, 2008). While much information is known about their migration (Engel, 1958; Wilber and Herrnkind, 1986), molting patterns (Cheung, 1973; Gleeson, 1980), mating behaviors (Savage, 1971; Jivoff and Hines, 1998), and reproductive life histories (Aguilar et al., 2008; Gerhart and Bert, 2008), only brief descriptions of grooming in these brachyuran crabs exist in the literature (Bauer 1981; Pearson and Olla, 1977; Simonson, 1985; Kuris, 1990).

Blue crabs and stone crabs are morphologically different, with stone crabs having larger cumbersome chelipeds and blue crabs having modified fifth pereopods for swimming (Churchill, 1919). Their habitats differ with blue crabs being active swimmers that frequently migrate in the water column and estuaries and even move several km/day (Gray, 1957; Ward, 2012). In stone crabs, migration is small (move at a rate of 6m/day; Bert, 1992) and live benthically in crevices near hypoxic or anoxic fine sediment in oyster beds and mudflats (Gray, 1957; Powell and Gunter, 1968; Bert et al., 1978; Sullivan, 1979; Zimmerman et al., 1989; Bert, 1992; Tankersley et al., 1998). Stone crabs are collected in highest densities in habitats of 
mud and burrow as adults (Bert et al., 1978; Bert, 1992); juveniles do not live in burrows (Bert et al., 1978). Because activity level of a crustacean has been predicted to impact fouling levels and thus grooming (Ra'Anan and Sagi, 1985), grooming behaviors and pressures of these two crab species are likely to be different.

This research addresses the lack of data on brachyuran grooming behaviors. Understanding how crabs groom their bodies is important to their overall body health and time allotment through the day. The objective of this study was to document the frequency and time of grooming behaviors of both blue and stone crabs, documenting body regions groomed, and by which grooming appendages. Blue crabs are predicted to have more body fouling due to their activity level while swimming in estuaries, exposing them to high sediment loads (Ward, 2012), and thus, should have more grooming behaviors than stone crabs. Both crabs are predicted to groom their respiratory and sensory structures more than other body regions. Based on their body morphologies (i.e. limited access to gills, larger chelipeds), crabs are predicted to have a lower time budget for grooming compared to shrimps.

\section{Material and Methods}

\section{Collection and laboratory procedures}

Blue crabs (Callinectes sapidus; family Portunidae; abbreviated BC in manuscript) and stone crabs (Menippe mercenaria; family Menippidae; abbreviated SC in manuscript) were collected in Tampa Bay, Florida in 2015. They were placed on commercial fiberglass aquaculture tanks (454-1) in continuous, filtered, and aerated saltwater $\left(25-30 \mathrm{ppt} ; 23-25^{\circ} \mathrm{C} ; 14\right.$ light: 10 dark lightcycle). Crabs were housed individually in containers that allowed water flow, but prevented physically interactions and cannibalism (Wilber, 1995; Lipcius et al., 2007). Carapace width (CW) of each crab was measured using digital callipers to the nearest $0.01 \mathrm{~mm}$ (following Ward, 2012 for BC; Savage and Sullivan, 1978 for SC); body mass was measured to the nearest $0.01 \mathrm{~g}$. Blue crab sizes at maturity vary between locations. Williams (1984) suggested that by CW $41 \mathrm{~mm}$ most individuals should be mature. Adults for stone crabs have a CW greater than $40 \mathrm{~mm}$ (Bert, 1992), so all individuals used in this study were mature adults. Crabs were fed every other day, but not on testing days. Any crab that molted or brooding eggs was not used. Crabs were allowed to acclimate in testing aquaria for 24-hr prior to test (24-hour, individual, and agonistic). Data on the two species were not pooled. Though out the manuscript, the following abbreviations will be used: second antennae (a2), first antennae (a1; antennule), blue crabs (BC), carapace width (CW), degrees of freedom (df), Kruskal-Wallis test statistic $(\mathrm{H})$, minute $(\mathrm{min})$, sample size $(\mathrm{N})$, p-value $(\mathrm{p})$, walking legs (p2-p5), coefficient of determination $\left(\mathrm{r}^{2}\right)$, seconds ( $\left.\mathrm{sec}\right)$, stone crabs (SC), Mann-Whitney $\mathrm{U}$ test statistic $(\mathrm{U})$, wet weight $(\mathrm{WW})$, chi-squared test statistic $\left(\chi^{2}\right)$, paired Wilcoxon-signed test statistic $(Z)$, third maxilliped ( $3 \mathrm{mxp})$, second maxilliped ( $2 \mathrm{mxp})$, first maxilliped (1 mxp) (Fig. 1A-C).

\section{4-hour observations}

The objective of these observations was to determine if crabs groom equally (in frequency) in day and night time hours. A 24-hr experiment was conducted for each species ( $\mathrm{BC}: \mathrm{N}=19$; $\mathrm{SC}: \mathrm{N}=21$ ) where observations were made every $30-\mathrm{min}$ for $24-\mathrm{hr}$ on crabs in isolation, housed in 38-1 tanks. Presence or absence of grooming during each 10 -sec observation was documented ( 0 = not grooming, 1 = grooming; 48 observations on each crab were made). During night-time hours when all lights were turned off (10 hrs; 20 observations), a red light lamp was used to make observations (Bauer, 1998). Data were pro-rated to account for more observations occurring in the daytime ( $14 \mathrm{hrs;} 28$ observations).

\section{Isolated grooming observations}

The overall objectives of these observations were to compare time budgets and grooming behaviors among genders, different sized individuals, and between each species. Grooming behaviors and time budgets can then be compared to those of other crustaceans. Crabs were tested individually; each crab was tested only one time. Individuals were placed into a 38-1 aquarium with black backing and natural rocky substrate. The static aquaria included aeration with a continually cycling filter; water was changed frequently with water from the aquaculture tanks. Crabs acclimated for 24-hr before testing (BC: total=59, females $\mathrm{N}=15$, males $\mathrm{N}=44$; $\mathrm{SC}$ : total $=60$, females $\mathrm{N}=19$, males $\mathrm{N}=41$ ). All grooming behaviors were documented for 30-min, using a 
A

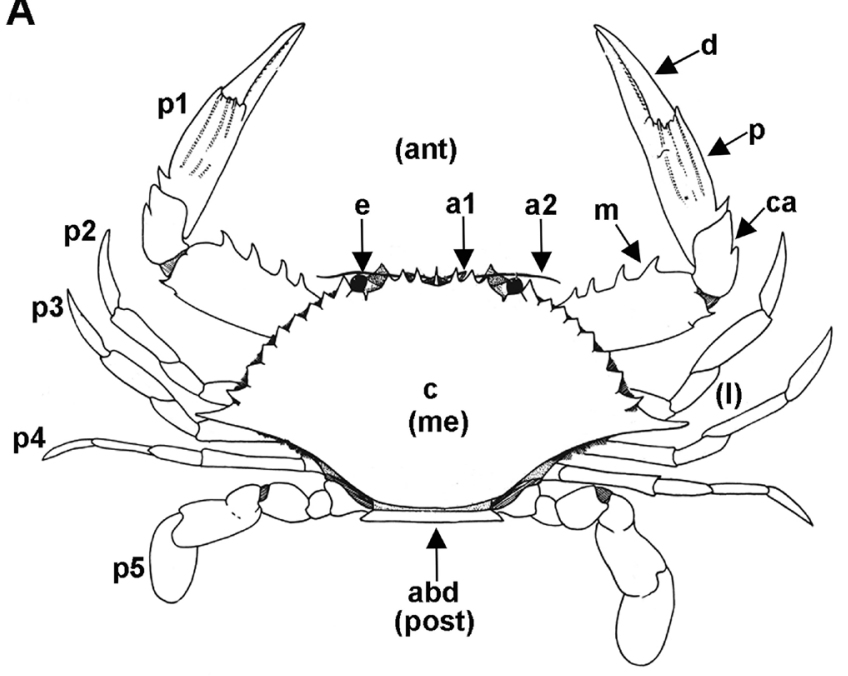

B

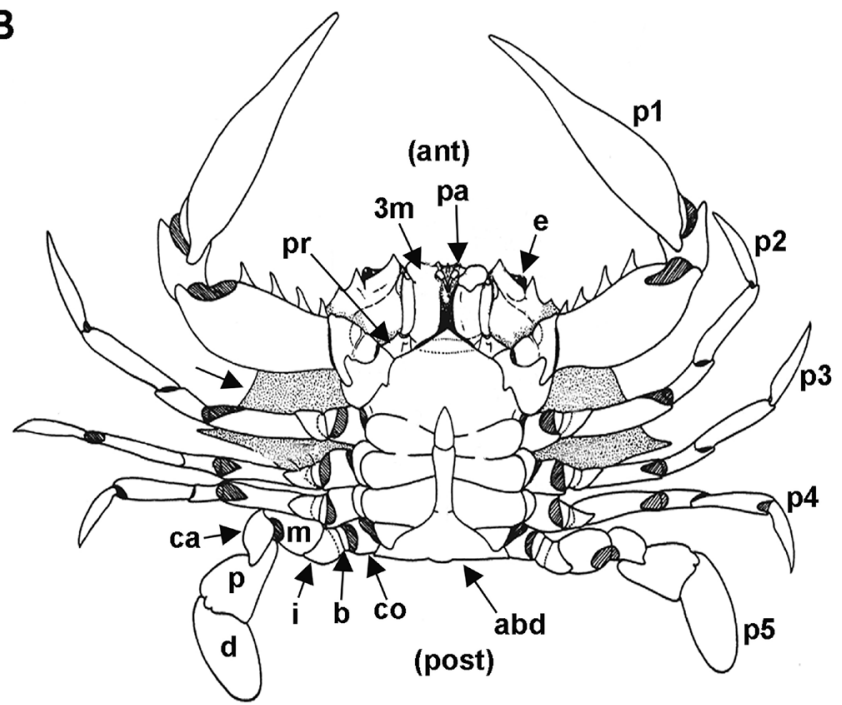

C

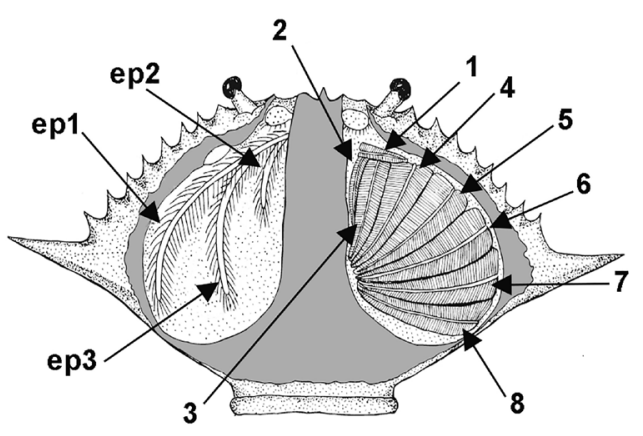

D

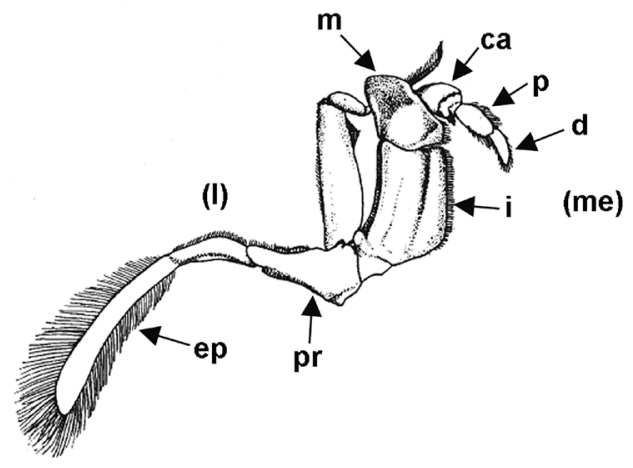

Figure 1. Anatomy of a brachyuran crab, Callinectes sapidus, with grooming appendages and groomed body regions labelled. Morphological structures are similar to Menippe mercenaria except for $\mathrm{p} 1, \mathrm{p} 5$, and gills (in Menippe, $\mathrm{p} 1$ is larger, $\mathrm{p} 5$ is similar to $\mathrm{p} 4$, and there are nine gills in a slightly different orientation). A. Dorsal body. B. Ventral body. C. Dorsal view of the internal branchial cavity with most of carapace removed, showing eight gills and three epipods. D. Third maxilliped morphology, with the palp (comprised the dactyl, propodus, and the carpus); the basis and the coxae are combined in the protopod. Note: 1-8=gill 1-8; a1=antennule, $\mathrm{a} 2=$ antenna, $\mathrm{abd}=\mathrm{abdomen}$, ant=anterior, $\mathrm{b}=$ basis, $\mathrm{c}=$ carapace, $\mathrm{ca}=$ carpus, $\mathrm{co}=$ coxae, $\mathrm{d}=$ dactyl, $\mathrm{e}=$ eyes, ep $1-3=$ epipod associated with maxillipeds, $\mathrm{i}=$ ishchium, $\mathrm{l}=$ lateral, $\mathrm{m}=$ merus, $\mathrm{me}=$ medial, $\mathrm{p}=$ propodus, $\mathrm{pa}=$ palp, post=posterior, pr=protopod, $\mathrm{p} 1=$ cheliped, p2-p5=walking legs, 3m=third maxilliped. Note: Body positions noted in parentheses. Figs. 1A-D modified from Kennedy and Cronin (2007).

digital recording device, and then later transcribed to data sheets (following methods of VanMaurik and Wortham, 2011). Data were analyzed to determine if there are differences in grooming behaviors between sexes and different sized individuals (continuous data; not in size classes), to determine what appendages and body areas are groomed and by what mechanism, if regions are groomed more frequently than other body regions, and to establish a time budget for grooming for blue and stone crabs.

\section{Agonistic interactions observations}

The objective of this experiment was to document grooming behaviors in an environment with physical contact (i.e. agonistic observations). Grooming activities in these agonistic interactions should be lower 
compared to the individual observations. Crabs were observed with a size-matched conspecific (less than $10 \%$ in body size; CW). Crabs had physical contact with the other individual of the same species in a section on the aquaculture tank and their grooming behaviors (as well as any other behaviors) were documented (BC: $\mathrm{N}=45$ trials; $\mathrm{SC}: \mathrm{N}=44$ trials). Crabs acclimated for 1 -hr in the test arena $(58 \mathrm{~cm} \times 41 \mathrm{~cm} \times 23 \mathrm{~cm})$ without any contact. Then, crabs were allowed to interact for 30-min and all behaviors were recorded.

\section{Bacterial fouling and gill ablation}

To determine the effectiveness and impact of gill grooming in both species, one grooming appendage (3mxp epipod; a grooming appendage that cleans the gills; Kennedy and Cronin, 2007) was removed from crabs. The $3 \mathrm{mxp}$ epipod can easily be removed with forceps, reaching into the opening (near the protopod) while leaving the rest of the 3 mxp intact. Crabs were then placed individually on the watertable. After 21 days, crabs were chilled, euthanized (Kinsey et al., 2003), the carapace removed, and then gills were swabbed and then streaked across agar plates, using aseptic techniques, on each side of crab, with one side of the crab having all three epipods present and the other side only having two epipods present (associated with the $1 \mathrm{mxp}$ and $2 \mathrm{mxp}$ ). While the $3 \mathrm{mxp}$ epipod mostly cleans ventral gills, only dorsal sides of gills were swabbed; assessing the gill ventral side was difficult and could not ensure sterile techniques. Plates were allowed to incubate at $37^{\circ} \mathrm{C}$ for 24-hr (BC: $\mathrm{N}=4$; SC: $\left.\mathrm{N}=10\right)$. Bacterial counts (colony forming units; $\mathrm{cfu}$ ) were made on each plate and data were compared between intact and non-intact sides of crabs (crab species were pooled due to low sample size in blue crabs caused by nongrooming behavioral complications). A control plate was swabbed and resulted in no bacterial growth.

One gill was then removed from each side of the crab (BC: $6^{\text {th }}$ arthrobranch gill; SC: $7^{\text {th }}$ arthrobranch gill). Gills were prepared using SEM techniques (Felgenhauer, 1987), critically-point dried, coated in gold-palladium, and viewed under the scanning electron microscope (JEOL JSM-6010A). Both ventral and dorsal gill sides were observed to account for long setae on epipods that may clean along both edges of gills (Aldridge and Cameron, 1982; Kennedy and Cronin, 2007; Ward, 2012). Gills were selected for examination were based on its presence in the branchial chamber, each was the largest gill and lay medially in the branchial chamber; posterior gills were not selected since they are involved mostly in osmoregulation of sodium and chloride (for BC, Aldridge and Cameron, 1982; Ward, 2012). Magnification ranges for blue crabs and stone crabs SEM images were 17X-170X and $17 \mathrm{X}-600 \mathrm{X}$, respectively.

\section{Statistical analyses}

Data did not meet criteria for parametric statistics, thus non-parametric statistics were used, such as Mann Whitney, paired Wilcoxon Sign, and Kruskal-Wallis tests, along with chi-squared tests. Time budgets were calculated for each individual, with the goal of determining the total time budget for grooming for each species and were calculated by adding total time spent grooming per observation and then dividing it by total time of the observation (30-min or 1800-sec). In agonistic observations, individuals cannot be treated as independent because actions of one individual may affect the other individual. Thus, total time groomed in a trial was determined by summing the inclusive grooming time of the two individuals and dividing by total time of the observation (3600-sec; 30-min trial of 1800 -sec; $\mathrm{N}=2$ individuals).

\section{Results}

\section{Population data and 24-hr observations}

Blue crabs used in this research were larger than stone crabs (BC—carapace width (CW): 66-236 $\mathrm{mm}$; 154 mean; wet weight (WW): 103-169 g; 139 mean; SC--CW: 49-95 mm; 70 mean; WW: 42-289 g; 147 mean). However, for blue crabs and stone crabs, males and females were of equal CW (BC: $\mathrm{U}=328$, $\mathrm{df}=58, \mathrm{p}=0.972$; $\mathrm{SC}: \mathrm{U}=350, \mathrm{df}=59, \mathrm{p}=0.530)$ and WW (BC: $U=281, d f=58, p=0.389$; SC: $U=378, d f=59$, $\mathrm{p}=0.855)$. Thus, males and females were the same body size, for both species. Both species groomed equally (in frequency) in day and night hours (BC: $U=120$, $\mathrm{df}=18, \mathrm{p}=0.182$; $S C$ : $\mathrm{U}=151, \mathrm{df}=20, \mathrm{p}=0.082$ ).

\section{Individual observations}

Overall, males and females of each species groom statistically the same for frequency (BC: $U=292$, $\mathrm{df}=58, \mathrm{p}=0.502$; $\mathrm{SC}: \mathrm{U}=350, \mathrm{df}=59, \mathrm{p}=0.530)$ and time (BC: $U=321, d f=58, p=0.869$; $S C: U=321$, 
$\mathrm{df}=59, \mathrm{p}=0.28)$. Thus, male and female observations were pooled for each species. Larger individuals (on a continuous $\mathrm{x}$-axis; not in categories) do not groom more than smaller individuals, even though they may have reached their terminal molt earlier and are not growing a new exoskeleton (frequency--BC: $\mathrm{r}^{2}=0.017$, $\mathrm{df}=58, \mathrm{p}=0.332$; $\left.\mathrm{SC}: \mathrm{r}^{2}=0.002, \mathrm{df}=59, \mathrm{p}=0.744\right)$; time-BC: $\mathrm{r}^{2}=0.007, \mathrm{df}=58, \mathrm{p}=0.538$; $\mathrm{SC}: \mathrm{r}^{2}=0.011, \mathrm{df}=59$, $\mathrm{p}=0.424)$. Thus, for each species, all individuals were pooled, regardless of size and sex.

The grooming mechanism used most frequently by both species was a scraping action; blue crabs did not brush or pick any body regions. Stone crabs used the scraping action most frequently, followed by brushing, and then picking (no statistical tests were done for $\mathrm{BC}$ as they only scrape; $\mathrm{SC}: \mathrm{H}=131, \mathrm{df}=59, \mathrm{p}<0.0001$ ). Scraping (quick grooms; $3.4 \mathrm{sec} /$ groom in stone crabs) occurred by taking an appendage or body region ( $3 \mathrm{mxp}$, chelipeds, eyes, and walking leg) in the same direction, one time; in contrast to the brushing motion (with the $3 \mathrm{mxp}$ and walking legs; longer grooming bouts of $4.4 \mathrm{sec} /$ groom in stone crabs) which involved going back and forth several times. Picking involved using chelipeds ( $\mathrm{p} 1$; the longest action of $14 \mathrm{sec} /$ groom in stone crabs).

Body regions that were commonly scraped included the a1, a2, eye, $3 \mathrm{mxp}$, mouth, cheliped, carapace, gills, abdomen, ventral body surface, and p2-p5 (Fig. 1B). The $3 \mathrm{mxp}$, cheliped, ventral body surface, and $\mathrm{p} 2-\mathrm{p} 5$ were commonly brushed. The picking action was done to the $3 \mathrm{mxp}$, the other cheliped, carapace, and p2-p5; picking was focused on gonopods/pleopods inside the abdomen of males.

Grooming appendages: Blue and stone crabs have several grooming appendages, mostly associated with mouthparts, but also including walking legs. Both crab species used their $3 \mathrm{mxp}$ as the most frequently used grooming appendage, followed by using walking legs (Fig. 2A; BC: $\mathrm{H}=403, \mathrm{df}=58, \mathrm{p}<0.0001$; SC: $\mathrm{H}=337$, $\mathrm{df}=59, \mathrm{p}<0.0001)$. The $3 \mathrm{mxp}$ was also the grooming appendage used for the most time; however, in stone crabs, walking legs were also used for long periods (Fig. 2B; $\mathrm{BC}: \mathrm{H}=350, \mathrm{df}=58, \mathrm{p}<0.0001$; $\mathrm{SC}: \mathrm{H}=292$, $\mathrm{df}=59, \mathrm{p}<0.0001)$.

For grooming purposes in both species, the $3 \mathrm{mxp}$ can be divided into several sections (Fig. 1D). The palp, comprised of dactyl, propodus, and carpus segments, often grooms the eyes, a1, a2, and other maxillipeds. The endopod, with the larger sections of merus and ischium, moves and often brushes the other maxillipeds. When the endopod is in motion, it subsequently moves the protopod, made of the coxa and basis segments (Kennedy and Cronin, 2007), which articulates with internal epipod (Fig. 1D). The movement of the protopod (sometimes called the Milne-Edwards aperture; Matsuoka and Suzuki, 2011) moves the third epipod, which ventrally cleans the gills by a passive action. Thus, every time the $3 \mathrm{mxp}$ endopod moves, posterior gills are also cleaned by the third epipod (BC: gills \#4-8; SC: gills \#6-9) (Fig. 1C).

In both crabs, second and first maxillipeds groom the other maxillipeds and mandibles and also have attached epipods inside the carapace (Fig. 1C). When these maxillipeds move, gills are also cleaned, similar to the action of the $3 \mathrm{mxp}$. The first maxilliped epipod is most dorsal and is the only epipod on the dorsal surface of the gills; this epipod cleans all gills dorsally (in both species). In contrast, $2 \mathrm{mxp}$ and $3 \mathrm{mxp}$ epipods are located ventrally, touching the ventral surface of the gills (the second epipod is smaller; $\mathrm{BC}$ : cleans anterior gills \#1-4; SC: cleans gills \#3-5). For SC, movement of the second epipod may clean the first two anterior gills (\#1-2) ventrally, but this was not clear. Overall, in terms of structure, all three epipods in stone crabs were specifically more robust with a thicker exoskeleton, compared to blue crabs.

For both crab species, setae are situated around each eye socket and when eyes move, these setae appear to clean it. The cheliped (pereiopod 1; pincher) is also a grooming appendage that usually picks body regions (in SC), but also scrapes the other cheliped with the propodus-carpus joint of $\mathrm{p} 1$. Along lateral and medial edges, walking legs have setae that scrape and brush the carapace, abdomen, and other walking legs. Male blue crabs use their abdomens to pick and clean, opening, closing, and using the distal tip of the telson most likely for cleaning the gonopods/pleopods. Sometimes, especially in blue crabs, individuals would use alternative objects (labelled "AO" in figures) in the tank, like glass or filter to scrape their body regions.

Groomed body regions: Overall, blue crabs groomed themselves an average of 56 times, with a range of 0-716 grooms in the 30-min trial, at a rate of 1.9 grooms/min (every $32 \mathrm{sec}$ ). Contrary to the 

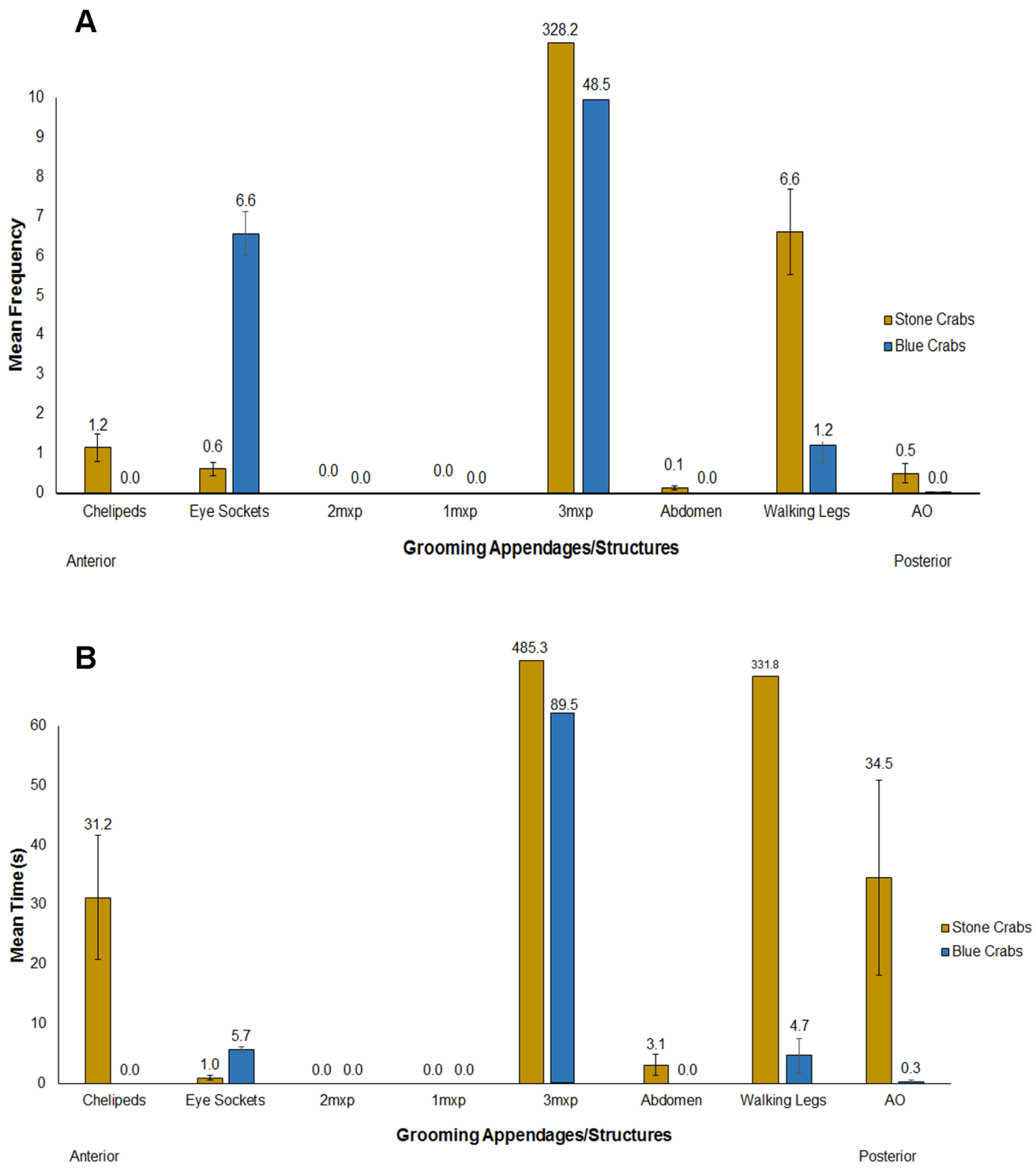

Figure 2. Grooming appendages of blue and stone crabs for individual observations ( 30 min trial). Decimal places were used to show exact data; rounding would have led to many " 0 ". A. The $3 \mathrm{mxp}$ is the most frequently used grooming appendage in both crab species. B. The $3 \mathrm{mxp}$ is the grooming appendage used for the most time, along with the walking legs and the cheliped. Note: $1 \mathrm{mxp}=$ first maxilliped, $2 \mathrm{mxp}=$ second maxilliped, $3 \mathrm{mxp}=$ third maxilliped, $\mathrm{AO}=$ alternative objects, $\mathrm{BC}=\mathrm{blue}$ crabs, $\mathrm{SC}=$ stone crabs.

hypothesis, stone crabs groomed themselves more frequently, with 348 grooms and a range of 30-877 grooms in the $30-\mathrm{min}$, at a higher rate than blue crabs of 11 grooms $/ \mathrm{min}$ (every $5.5 \mathrm{sec}$ ). The most frequently groomed body regions in both crab species were the gills, followed by the antennae and antennules, and then maxillipeds (Fig. 3A; BC: $\mathrm{H}=343$, df=58, $\mathrm{p}<0.0001$; SC: $\mathrm{H}=455, \mathrm{df}=59, \mathrm{p}<0.0001)$. While gills were still groomed for the most time in both species, carapace, walking legs, chelipeds, and antennae are groomed for long time periods, especially in stone crabs (Fig. 3B; $B C: H=336, d f=58, p<0.0001$; $S: H=321, d f=59$, $\mathrm{p}<0.0001)$.

Overwhelmingly, for both blue and stone crabs, when sensory ( $11, a 2$, eyes, $3 \mathrm{mxp}$ ) and respiratory structures (gills) when grouped together, they were groomed more frequently than other appendages and body regions, in both species ( $\mathrm{BC}: \chi^{2}=370, \mathrm{df}=58$, 

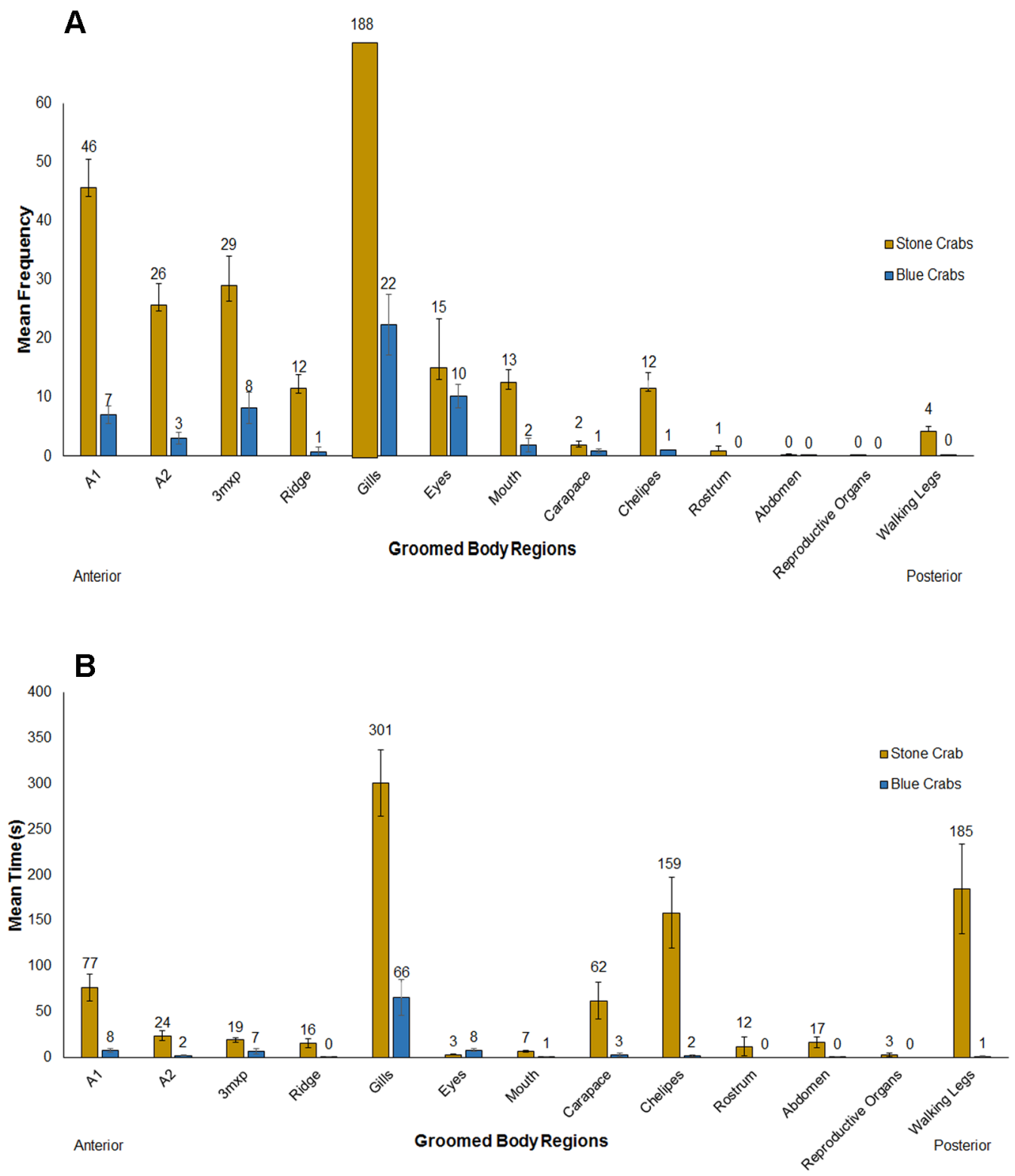

Figure 3. Groomed body regions of blue and stone crabs for individual observations ( $30 \mathrm{~min}$ trial). A. The gills, antennae, antennules, and maxillipeds are the most frequently groomed body regions for both species. B. The gills, carapace, walking legs, chelipeds, and antennae are groomed for the longest time periods in both species. Note: $1 \mathrm{mxp}=$ first maxilliped, $2 \mathrm{mxp}=\mathrm{second}$ maxilliped, $3 \mathrm{mxp}=$ third maxilliped, $\mathrm{Al}=$ antennules, $\mathrm{A} 2=$ antennae, $\mathrm{AO}=$ alternative objects, $\mathrm{BC}=\mathrm{blue}$ crabs, $\mathrm{SC}=$ stone crabs.

$\mathrm{p}<0.0001$; SC: $\left.\chi^{2}=266, \mathrm{df}=59, \mathrm{p}<0.0001\right)$. However, while blue crabs did groom this grouping for more time than all other body regions, stone crabs behaved oppositely and groomed all other body regions for more time than sensory/respiratory structures $\left(\mathrm{BC}: \chi^{2}=359\right.$, $\mathrm{df}=58, \mathrm{p}<0.0001$; $\left.\mathrm{SC}: \chi^{2}=141, \mathrm{df}=59, \mathrm{p}<0.0001\right)$. All combined body regions included the carapace ridge, carapace, chelipeds, mouth, rostrum, abdomen, gonopods/pleopods, and walking legs (8 combined body regions). Looking at functionality of body regions groomed, stone crabs groomed respiratory structures more often than sensory structures, but blue crab behaviors were inverse with more grooming to sensory structures (Fig. 4A; $\chi^{2}=455, \mathrm{df}=58, \mathrm{p}<0.033$; SC: $\left.\chi^{2}=102, \mathrm{df}=59, \mathrm{p}<0.0001\right)$. However, when looking at time spent grooming these functional body regions, stone crabs still groomed respiratory structures for more time than sensory structures, but blue crabs 


\section{A}

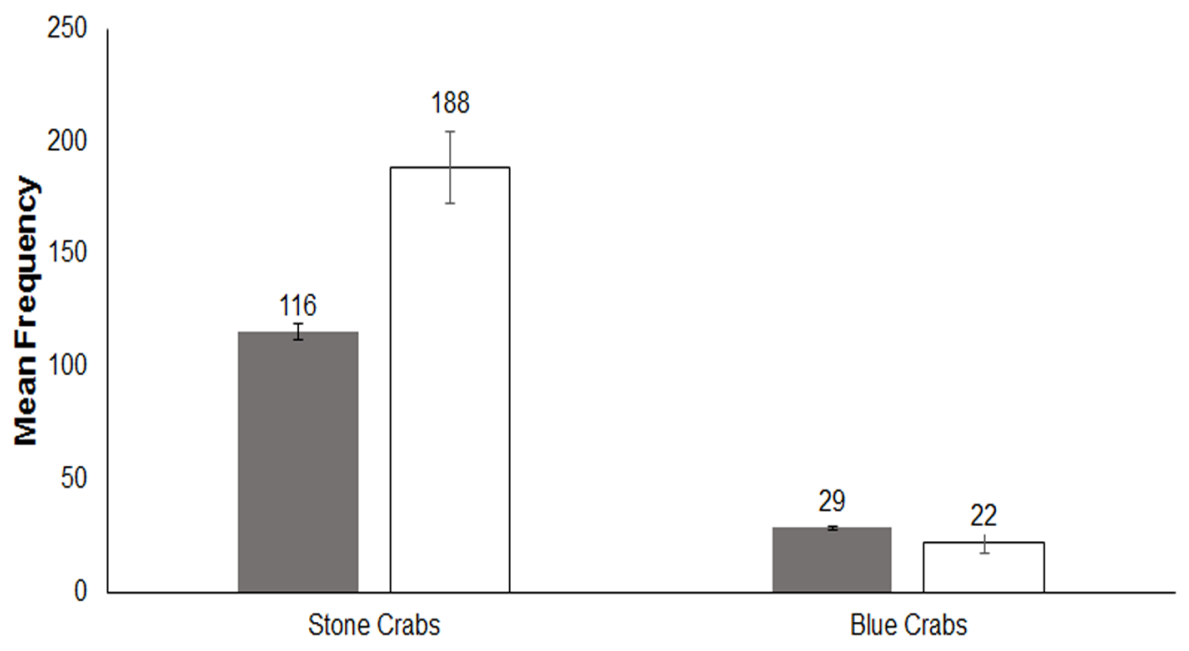

B

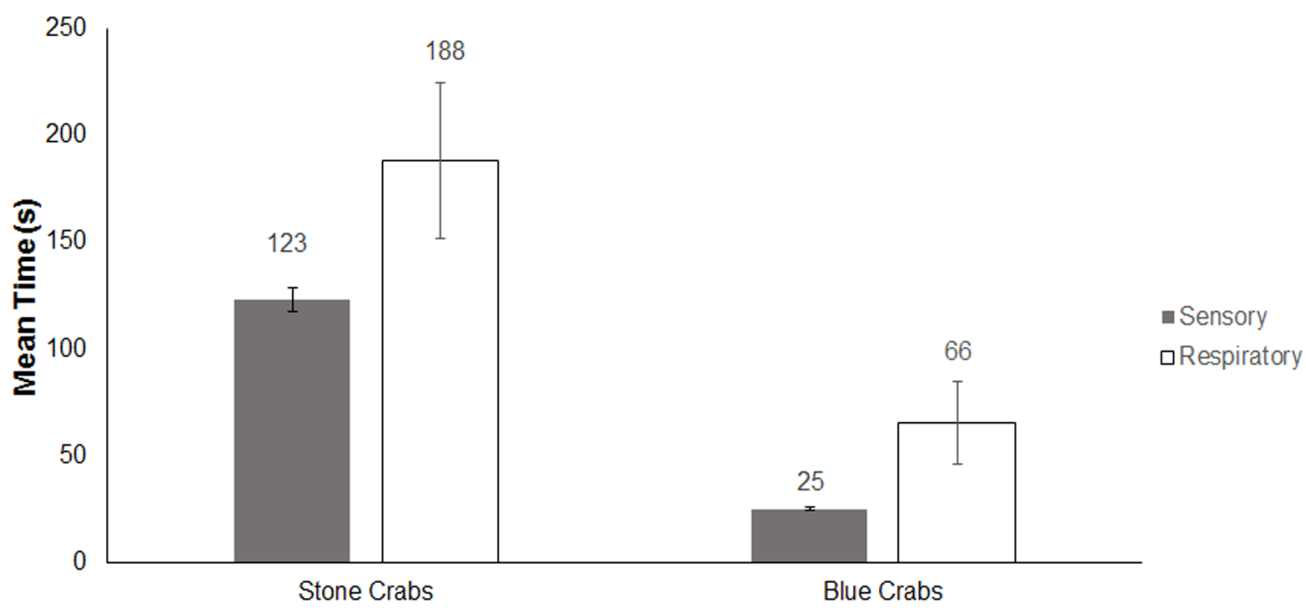

Figure 4. Grooming of functional body regions in blue and stone crabs for individual observations (30 min trial). A. Respiratory structures (gills) are groomed more often than sensory structures (antennules, antennae, eyes, and third maxillipeds) in both crab species. B. Time-wise, stone crabs groomed their respiratory organs more than sensory structures, but blue crabs groomed these two functional regions equally. Note: $\mathrm{BC}=$ blue crabs, $\mathrm{SC}=$ stone crabs.

groomed these two functional groups equally (Fig. $4 B ; B C: \chi^{2}=381, d f=58, p<0.051 ; S C: \chi^{2}=101, d f=59$, $\mathrm{p}<0.0001)$.

Overall, blue crabs groomed themselves for an average of 2 -min (in the 30-min observations), with a range of $0-\mathrm{sec}-20-\mathrm{min}$. Stone crabs groomed themselves much longer, with an average of 15 -min (in the 30-min observations), with a range of 30-sec63-min. The overall time budget for grooming for blue crabs was 5\% (range 0\%-66\%) and 49\% for stone crabs (range was 2\%-211\%). Crabs can groom more than one body region at the same time and thus their time budget can actually appear to be over $100 \%$.

\section{Agonistic observations}

Both crab species groomed more frequently and for more time than other behaviors (frequency-Fig. 5A: $B C: H=133, d f=44, p<0.0001$; SC: $H=122$, 


\section{A}

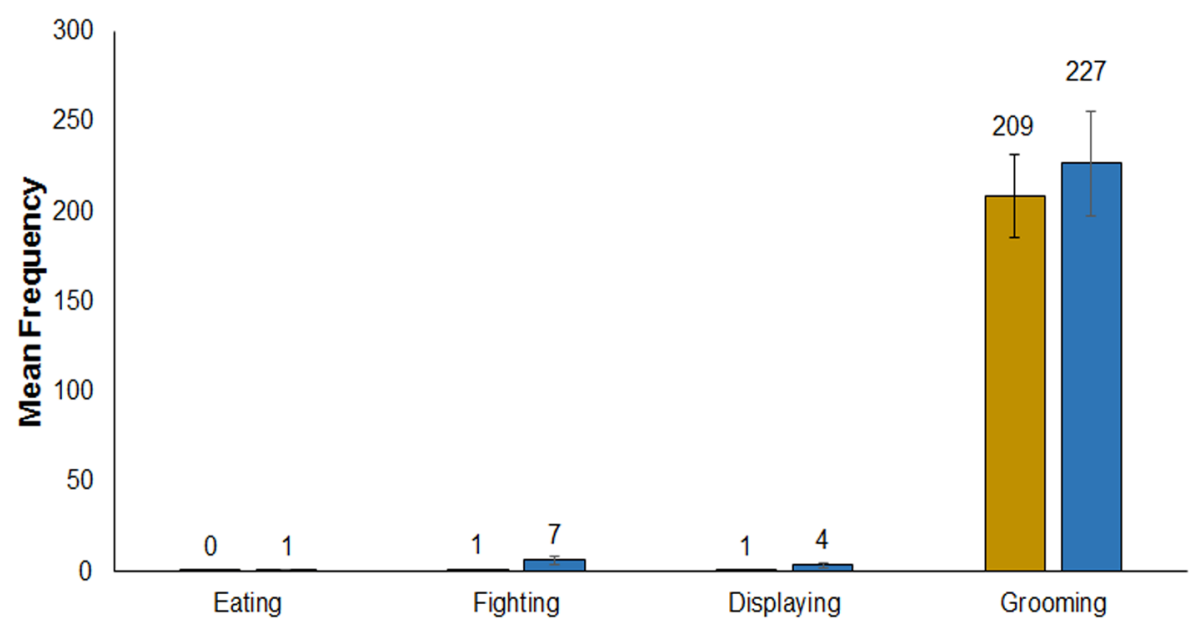

$\square$ Stone Crabs

-Blue Crabs

B

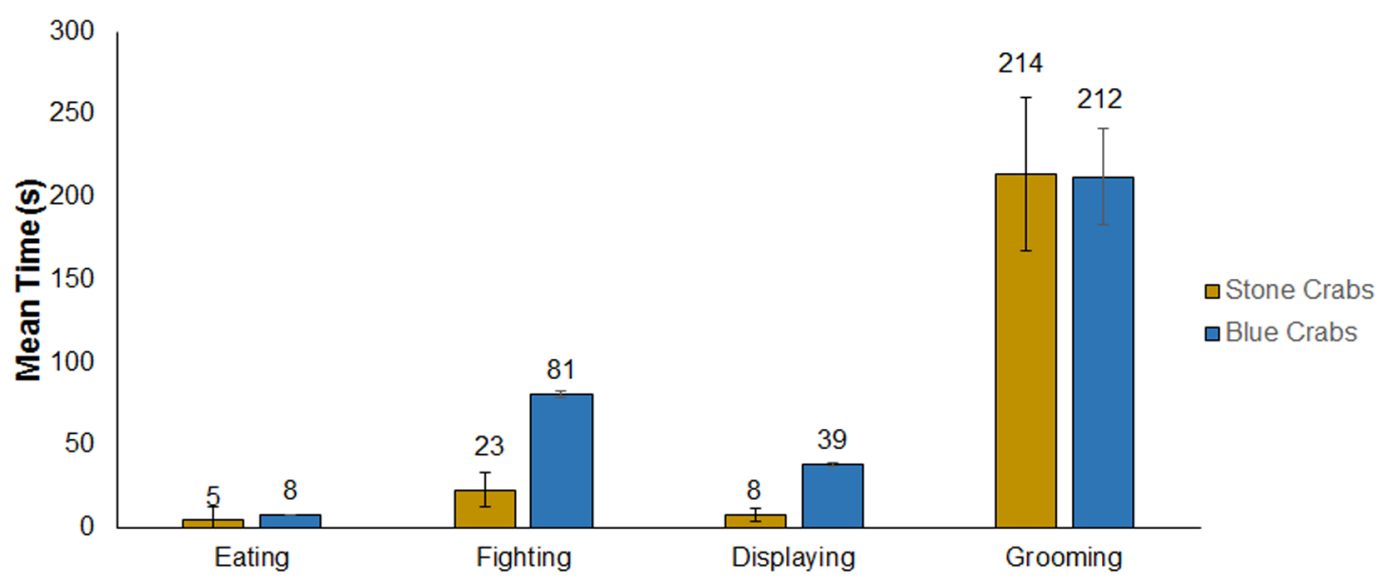

Figure 5. Agonistic behaviors in blue and stone crabs ( $30 \mathrm{~min}$ trial). A. Grooming was the most frequent behavior for both species. B. Both crab species spent more time grooming, followed by fighting and displaying. Note: $\mathrm{BC}=$ blue crabs, $\mathrm{SC}=$ stone crabs.

$\mathrm{df}=43, \mathrm{p}<0.0001)$; time--Fig. $5 \mathrm{~B}: \mathrm{BC}: \mathrm{H}=112, \mathrm{df}=44$, $\mathrm{p}<0.0001$; SC: $\mathrm{H}=117, \mathrm{df}=43, \mathrm{p}<0.0001)$. Both species spent more time grooming than fighting (BC: $U=319, d f=44, p<0.0001$; $S C: U=56, d f=43$, $\mathrm{p}<0.0001)$. Overall, in agonistic interactions, blue and stone crabs spent more time being non-active ( $80 \%$ and $72 \%$, respectively) with no obvious behaviors, compared to active categorical activities $(20 \%$ and $28 \%$, respectively) (BC: $\chi^{2}=71, \mathrm{df}=44, \mathrm{p}<0.0001$; SC: $\left.\chi^{2}=65, \mathrm{df}=44, \mathrm{p}<0.0001\right)$. The time budget for grooming was statistically different, compared to individual observations for both species $\left(\mathrm{BC}: \chi^{2}=33\right.$, $\mathrm{df}=103, \mathrm{p}<0.001$; $\left.\mathrm{SC}: \chi^{2}=30, \mathrm{df}=103, \mathrm{p}<0.0001\right)$. For blue crabs, agonistic grooming time budget increased to $13 \%$ (from $5 \%$ in individual observations) with a range of $2.5 \%-26 \%$, whereas in stone crabs, agonistic grooming time budget decreased to $12 \%$ (from $49 \%$ in individual observations) with a range of $1.5 \%-30 \%$. Stone crabs have a higher time budget than blue crabs in individual observations ( $49 \%$ and $5 \%$, respectively) 
$(\mathrm{U}=263, \mathrm{p}<0.0001)$, however their time budgets are statistically similar in agonistic observations (12\% and $13 \%$, respectively) $(\mathrm{U}=799, \mathrm{p}=0.117)$.

\section{Bacterial fouling and gill ablation}

In blue crabs, pairs of eight gills were observed as reported in the literature (Kennedy and Cronin, 2007) (Fig. 1C). However, for stone crabs, the gill formula appears to be undocumented in the literature. On each side, stone crabs have nine gills; gill \# 1 is a podobranch attached to the $2 \mathrm{mxp}$; gill $\# 2$ is a podobranch attached to the 3mxp. Gills \#3-7 are arthrobranchs and gills \#8-9 are pleurobranchs. Gill \#5 was compressed in all crabs observed.

From SEM images, there is evidence of fouling in both species, mostly from sedimentary sources. Bacteria were not visible at magnification levels. Results from bacterial plate and cfu counts resulted in no statistical differences between ablated and nonablated grooming appendage sides of the body. With both crab species combined, there was equal bacterial fouling for both body sides $(\mathrm{N}=14 ; \mathrm{Z}=-1.59 ; \mathrm{p}=0.112)$. No fouling epibionts on either species were observed. However, for individuals in both species with an ablated third epipod, higher levels of fouling were present on gills compared with individuals with all gill grooming appendages present.

Specifically for blue crabs missing a grooming appendage, gill lamellae and the dorsal central axis were heavily fouled and simple setae on the central axis were either broken, missing, or covered in fouling (Fig. 6A, B). Looking at the ventral side, ablated individuals had more fouling (sedimentary and filamentous algae) and damaged setae than non-ablated individuals (Fig. 6C,D). Similar fouling in stone crabs was also observed, with non-ablated individuals having gills with low fouling levels (Fig. 6E). Ablated individuals had fouling between their lamellae (Fig. 6F) and even had larger fouling materials protruding from the gills (Fig. 6F). A close up examination of lamellae shows sedimentary fouling on the central axis and between lamellae on ablated crabs, compared to intact crabs (Fig. 6G, H).

\section{Discussion}

While much information exists on grooming in caridean shrimps, little is known about grooming in other decapods (Martin and Felgenhauer, 1986). The overall grooming behaviors of blue and stone crabs yielded similar results, with males and females having the same grooming behaviors, as did larger and smaller individuals, within each species. Males and females having similar behaviors is surprising, especially in blue crabs, where females have different life history characteristics (higher migration rates; Ward, 2012) than males that could lead to them being exposed to different fouling pressures. Many researchers (review in Ward, 2012) have documented that female blue crabs are impacted by parasites more than males. Females also have a terminal molt whereas males necessarily do not; after maturity, male intermolt periods do increase but they can continue molting (Haefner and Shuster, 1964; Ward, 2012). Because ovigerous females were not used in this study, future research could address grooming behaviors of females brooding eggs.

The mechanisms for grooming were similar to that observed in other crustaceans, using a scraping, brushing, and picking action (Martin and Felgenhauer, 1986; VanMaurik and Wortham, 2011). Blue crabs not picking or brushing their bodies was surprising. Blue crab chelipeds are more dexterous and similar to each other in size and shape (slight differences in color and function have been reported; Govind and Blundon, 1985; Ward, 2012), compared to stone crabs; however, blue crabs do not use their chelipeds often to groom. Because stone crabs cannot effectively pick their bodies with their cumbersome major or minor chela, the mechanism for using the chelipeds was rarely picking, but instead scraping of the cheliped on other body regions, mainly the other cheliped. This behavior appeared for purpose of grooming, not the communication behavior that involves rubbing their cheliped against the anterior carapace (Sinclair, 1977). However, even though accounting for only $2 \%$ of all grooming, their chelipeds do serve an important role in communication, grooming, and cleaning the body. Thus, when one cheliped is removed in the fishery of stone crabs, grooming of the body, especially other remaining and highly important cheliped, would be reduced.

\section{Grooming behaviors}

The $3 \mathrm{mxp}$ is the most used grooming appendage for both species and is frequently associated with internal grooming of the gills by the attached epipods. Stone 


\section{Blue Crabs}
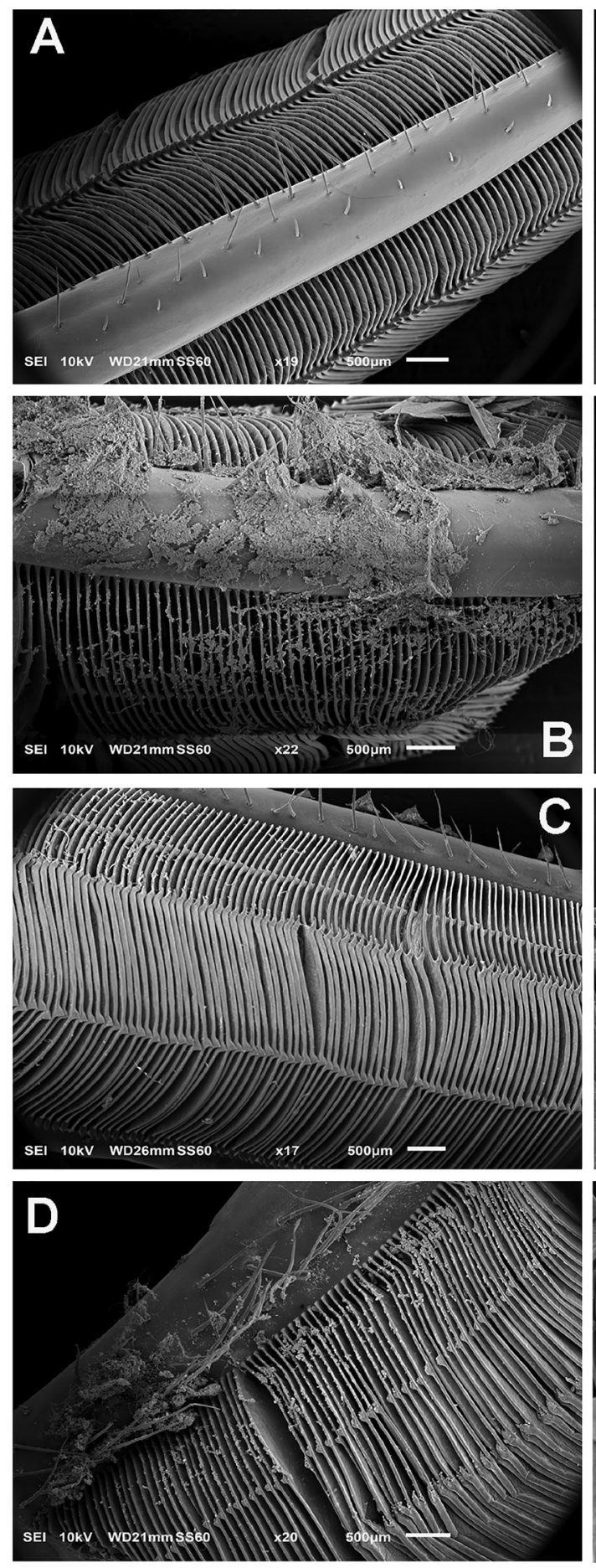

Stone Crabs
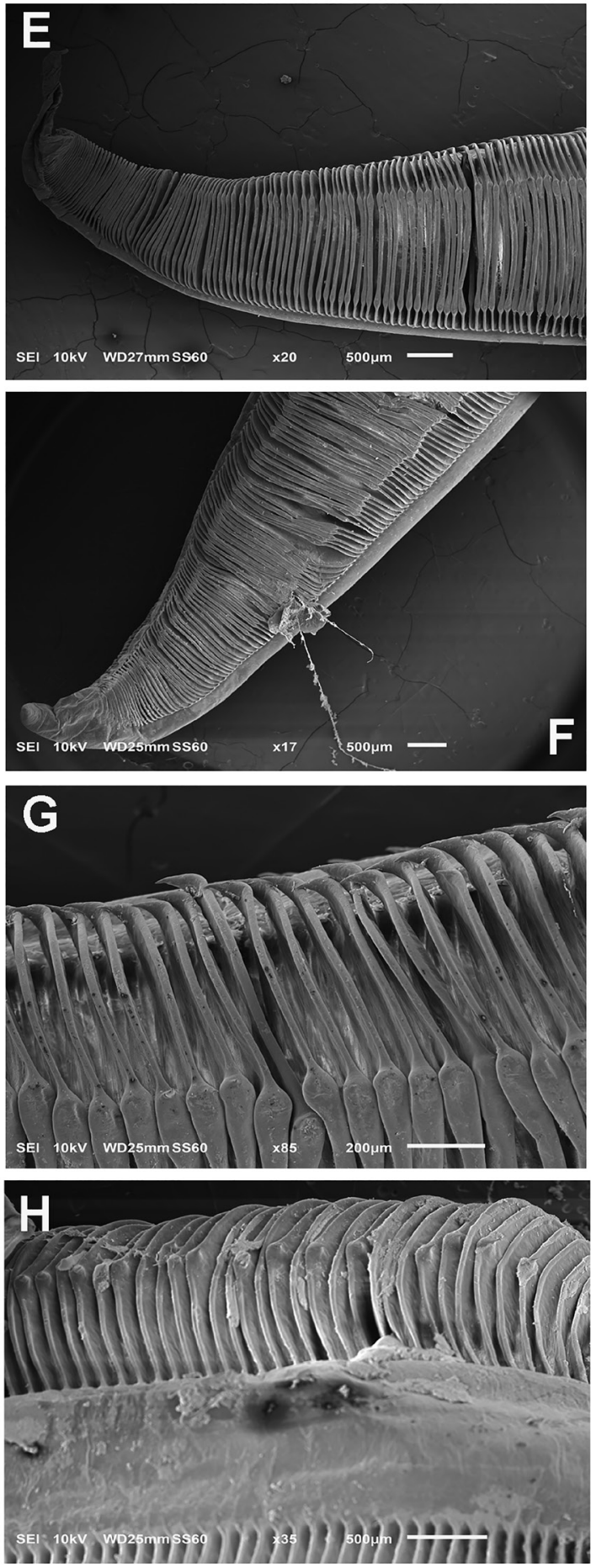

Figure 6. Scanning electron microscope images of gill fouling in blue (gill \#6) and stone crabs (gill \#7). A. Blue crab dorsal side of gill, with all grooming appendages present, showing minimal fouling, and simple setae along the central axis. B. Blue crab ablatedside of dorsal gill, with third epipod removed, showing evidence of fouling along the central axis, between lamellae, and covering setae. C. Intact blue crab, side of ventral gill, showing minimal fouling levels and visible simple setae. D. Blue crab ablated-side of ventral gill showing fouling along the central axis, in between lamellae, and covering the simple setae. E. Stone crab, side of ventral gill, with all grooming appendages present, showing minimal fouling. F. Stone crab ablated-side of ventral gill with third epipod removed, showing evidence of fouling between lamellae with fouling protruding from a singular lamellae. G. Intact stone crab gill showing low fouling levels between lamellae. H. Stone crab with ablated grooming appendage, showing fouling along the dorsal central axis and between lamellae. 
crabs did use their walking legs and chelipeds more than blue crabs, possibly due to the swimming function and morphology of the p5 in blue crabs (Ward, 2012). An anomuran crab had similar grooming appendages (3mxp and p5; Martin and Felgenhauer, 1986). While many decapod walking legs are chelate, blue and stone crabs p2-p5 are not chelate (Kennedy and Cronin, 2007); thus, no picking mechanism can be used by walkinglegs, compared to other decapods. The gills were groomed more than other body region. Interestingly, while the gills, antennae, and antennule grooms were done quickly (1-sec grooms), carapace, chelipeds, and walking legs were groomed less frequently, but for longer periods. Stone crabs did use their walking legs and chelipeds as grooming appendages, but also spent long bouts of time grooming these same pereiopods; thus these appendages groom and are also groomed.

In terms of the functions of body regions groomed for blue and stone crabs, gill grooming is likely important to help keep particulate matter off the gill surface area and to decrease settlement of epibionts. Thus, functionality of grooming the gills, increasing respiration, is a priority in their grooming time budget. Grooming sensory organs, like antennules, antennae, and eyes, are also a frequent and large component of their grooming time budget, with antennules and antennae being involved in equilibrium, prioproception, mechanoreception, and chemoreception (Kennedy and Cronin, 2007). These specific functional body regions (respiration and sensory reception organs) are locations where grooming is focused and this is similar to other crustaceans (VanMaurik and Wortham, 2014). For both crabs, walking legs are important for tactile and mechanoreception and keeping these joints and setae free of fouling may be a high priority, especially in stone crabs. Interestingly, body regions groomed in these brachyuran crabs were similar to body regions groomed in an anomuran crab (Martin and Felgenhauer, 1986).

Larger crabs were predicted to groom more and for more time than smaller crabs, due to the length of time after their terminal molt for females and increased intermolt times in males (Ward, 2012). Because molting sheds fouling on their carapace, gills, and appendages, a terminal molt (or longer intermolt periods) would result in more fouling on all body regions, with larger and older individuals having higher levels of fouling
(Bauer, 1989). However, large and small individuals groomed equally (low $\mathrm{r}^{2}$ values). The terminal molt, or decreased number of molts, does not appear to be a factor influencing grooming for either of these brachyuran species. It is possible that higher surface area to volume ratios for smaller crabs (leading to more area where fouling can accumulate) balances fouling pressures associated with reaching a terminal molt in large crabs (leading to less reliable cleaning bouts like molting).

In stone crabs, time budgets for grooming decreased in agonistic interactions with a conspecific (from $49 \%$ to $12 \%)$. This decrease supports the idea of grooming being secondary. However, for blue crabs, time budgets actually increased in conspecific interactions (from $5 \%$ to $13 \%$ ), which seems to provide conflicting evidence that grooming is secondary. For both species, grooming was a behavior that occurred more than fighting. While most crabs did engage in displaying and fighting behaviors, these behaviors did not occur frequently, but these interactions lasted for longer periods, compared to frequent but short time/event of grooming behaviors. Regarding the low frequency of these interactive behaviors, individuals may judge their conspecific and then decrease any competition or dangerous behaviors in association with their neighbor, predicted by the dear enemy hypothesis (Jaeger, 1981).

Data suggests that both crab species are spending much time being inactive compared to active behaviors, such as fighting, displaying, feeding, and moving. During this time of categorized inactivity, crabs could be engaging in other important behaviors and physiological processes that were note recognized in this study. Looking at their active time, grooming is the main behavior in that category.

\section{Time budget}

The time blue crabs and stone crabs dedicated to grooming was variable. Compared to blue crabs (5\%), stone crabs groomed themselves more frequently and for more time, having a time budget of $49 \%$. Interestingly, blue crab and stone crab time budgets were statistically equal in interactions with conspecifics. Other time budgets for grooming in crustaceans in individual observations are presented (Fig. 7). Stone crabs have the highest grooming time budget for any documented crustaceans, with blue crabs being lower 


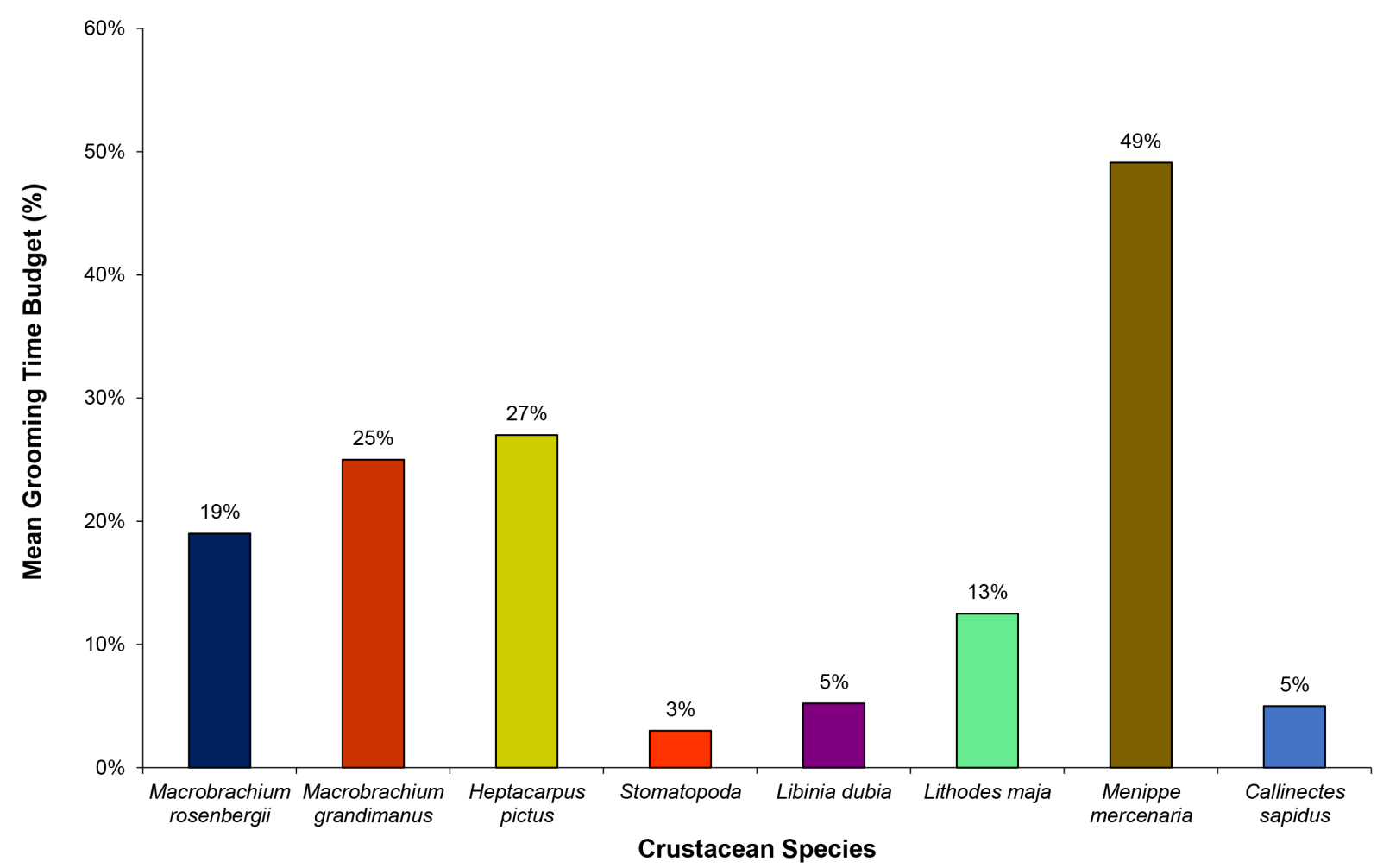

Figure 7. Grooming time budgets in crustaceans, in individual observations, with blue and stone crab data from this research. Note: Macrobrachium rosenbergii (Wortham et al., 2014), Macrobrachium grandimanus (VanMaurik and Wortham, 2011), Heptacarpus pictus (Bauer, 1981), stomatopods (Bauer, 1987; Wortham, 2008), Lithodes maja (Pohle, 1989), Libinia dubia (Jedlicka and Wortham, 2014).

than most shrimps (around 24\%; VanMaurik and Wortham, 2014). Brachyuran crabs may have variable time budgets that are directly related to activity levels and habitat. While being active has been associated with higher fouling pressures in shrimps (Bauer, 1978; 1981; 1989), active crabs may have lower fouling pressures because of: 1) increased water flowing through their branchial chamber, 2) being near higher currents which could remove fouling from body regions, and 3) not inhabiting benthic sediment. Stone crabs adults burrow in benthic sediment that may have a high silt/ clay content and also live in crevices near oyster beds (Bert et al., 1978; Bert, 1992). The high grooming time budget of stone crabs may be a result of the increase of fine particle exposure to gill chambers, their joints, and sensory reception organs.

It is possible that life history characteristics of blue crabs influence their lower time budget for grooming. Blue crabs swim several km/day as an adult (Ward, 2012). They often live in seagrass beds and swim in water columns and currents (Ward, 2012) that decrease the settling of sediment and debris. While blue crabs are active and are exposed to different environments during their migrations, their activity levels are highest at night and not during day/light hours when epibionts could grow and increase fouling levels; blue crabs are most active at nighttime (Hench et al., 2004). Along with not being constantly bathed in burrows of clay/silt sediment (burrowing is shallow and seasonal in blue crabs; Ward, 2012), blue crabs may not need to groom as often, even though they are highly active (Tab. 1).

\section{Fouling}

While Ward (2012) reviewed all parasitic fouling organisms in blue crabs, none was seen on exterior surfaces of the blue crabs or stone crabs used in this study. Fouling, mostly sedimentary, is concentrated between lamellar sheets in gills, similar to that found in crabs (Martin and Felgenhauer, 1986). These areas between lamellae became heavily fouled when a epipod was removed. The more sediment in between lamellae, less flow can move through those areas, and gill surface area in contact with water will decrease. Thus, it appears that epipod grooming appendages attached to all three 
Table 1. Life history characteristics of blue and stone crabs and the impact of these characteristics on fouling. Blue crabs have lower fouling pressures from their environment compared to stone crabs. Stone crabs may need to groom more than blue crabs based on their exposure to fouling.

\begin{tabular}{lcc}
\hline Life History Characteristic & Blue Crabs & Stone Crabs \\
\hline Water flow & $\uparrow$ & $\downarrow$ \\
Current exposure & $\uparrow$ & $\downarrow$ \\
Habitat of fine sediment & $\downarrow$ & $\uparrow$ \\
Activity level & $\uparrow$ & $\downarrow$ \\
Light exposure & $\downarrow$ & $\uparrow$ \\
Time spent in burrow/cervice & $\downarrow$ & $4: 2$ \\
Ratio of High: Low Fouling Pressures & $1: 5$ & $\uparrow$ \\
Fouling exposure & $\downarrow$ & \\
\hline
\end{tabular}

maxillipeds are successful in removing fouling from these respiratory structures.

There was not difference in bacterial levels for gills with the $3 \mathrm{mxp}$ epipod removed as compared to crabs with all branchial chamber-grooming appendages in tact. The $3 \mathrm{mxp}$ epipod, which cleans most of the ventral gill sides, was removed. The sterile methodology of swabbing gills involved the dorsal side of the gills. The methodology was developed with the hypothesis that long setae on epipods could reach the dorsal side, especially due to the water currents created by the epipodal motion (Kennedy and Cronin, 2007). Thus, methodology used for assessing bacterial levels was not without problems, as the ventral gill side (where the epipod was removed) was not directly sampled. Removing the first epipod (on the dorsal side of gills) would have been difficult due to size and location of the first maxilliped; the $1 \mathrm{~m}$ would likely have been damaged, leading to extra stress on the animal. In addition, it is possible that epipod setae are not efficient in removing bacteria from gill structures, but are efficient in removing sediment and filamentous algae.

Many researchers examine gill-cleaning structures and mechanisms in crustaceans (Bauer, 1998; 1999; Batang and Suzuki, 1999; 2000; 2003b); however, few have investigated brachyuran crabs (Batang and Suzuki, 2003a; Maksuoka \& Suzuki, 2011), and little data exists for the morphology of stone and blue crab gills. Brachyuran crabs have mostly phyllobranchiate gills (MacLaughlin, 1982), with blue crabs having the following gill types for their 8 gills (based on descriptions in MacLaughlin, 1983): 2mxp: 1 podobranch, 1 arthrobranch; $3 \mathrm{mxp}$ : 2 arthrobranchs; p1: 2 arthrobranchs, p2: 1 arthrobranch; P3: 1 pleurobranch (Kennedy and Cronin, 2007). Aldridge and Cameron (1982) describe the first four anterior gills of blue crabs, mostly involved in respiration whereas posterior gills are important in osmoregulation of sodium and chloride. The first two gills, associated with the $2 \mathrm{mxp}$, are small and one is described as not even phyllobranchiate (the arthrobranch at the $2 \mathrm{mxp}$; Kennedy and Cronin, 2007). The central axis, or medial septum, divides gills into anterior and posterior sections, with hair-like projections (setae) on the posterior ventral side (Aldridge and Cameron, 1982). Besides the current study, no gill descriptions have been reported for stone crabs in the literature. Thus, while gills of these two species are different in number, types, locations, and functions, keeping them clean is equally important.

Morphologically, blue crabs have a gill area of 54\% more than stone crabs (Gray, 1957) and thus have more area to become fouled and thus need to groom. Even though blue crabs groom less than stone crabs, their gill area was clean. Thus, even with having much more surface area and grooming for less time, blue crabs are able to keep this body regions relatively clean and might be relying on other anti-fouling mechanisms other than epipodal grooming behaviors.

Other anti-fouling behaviors or mechanisms exist in crustaceans. Molting rids the body of fouling as the exoskeleton is shed along with gills (Ward, 2012); thus, every time molting occurs (18-20x in a blue crab's life; Ward, 2012), the individual has a new clean external body and internal gills. Crustaceans can also reverse the water flow in the branchial chamber every minute and last several seconds; this behavior (often called the crustacean cough) flushes the gills, circulates water over their posterior gills, and decreases fouling inside 
the gill chamber (Arudpragasm and Naylor, 1964; Bill and Thurberg, 1985; Martin and Felgenhauer, 1986; Warner, 1977). Specialized setae on grooming appendages situated on the water intake openings (Milne-Edwards opening; protopod) and in the gill chamber can remove fouling (Martin and Felgenhauer, 1986; Wortham and LaValle, 2016). In terms of other animals aiding in eliminating fouling, blue crabs have a symbiotic oyster drill that attaches to the crab and eats fouling organisms off its carapace (Cake 1983). Thus, active and passive grooming by appendage use is just one important mechanism by which crabs can rid their bodies of fouling.

\section{Conclusions, Importance, and Significance}

Regarding predicted hypotheses, blue crabs did not have more obvious fouling in their gill area compared to stone crabs, nor did blue crabs groom their bodies more than stone crabs. Activity level and environmental exposure did not seem to influence grooming behaviors in these crabs as predicted. While respiratory and sensory structures are groomed frequently and for much time as expected, stone crabs do groom their walking legs for more time, suggesting an importance to keeping these appendages and their articulations clean. Blue crabs had a lower grooming time budget for grooming compared to shrimps as predicted, but stone crabs grooming time was much higher than for any reported crustaceans. Overall, there is considerable evidence that the grooming appendages are effective in removing fouling from the body and these appendages and environmental fouling impacts their associated setal structures.

Documenting grooming time budgets and grooming behaviors for commercially important brachyurans allow a better understanding of daily requirements of this decapod group. In addition, there are large differences in grooming time and body regions groomed between crabs and shrimps, likely due to the gill location inside the enclosed carapace in crabs. These differences have been predicted to be important in understanding phlyogeneic relationships between taxonomic groups (Bauer, 1981; Martin and Felgenhauer, 1986).

Especially for stone crabs that often lose a cheliped in the fishery, this grooming appendage loss can influence the efficiency of grooming in this species.
Habitat change, especially a large influx of river waters into an estuary (Ward, 2012), could increase the grooming pressures for both these species and lead to further fouling of respiratory and sensory organs. Blue crab biomass in populations has decreased by $70 \%$ (between years of 1982-2005) in some locations (Ward, 2012), likely because of overfishing, low water quality, habitat changes, and/or diseases/parasite loads. Thus, monitoring these factors, which would influence grooming, is essential.

\section{ACKNOWLEDGEMENTS}

The University of Tampa Summer Fellowship, Dana Foundation Grant, and a David Delo Research Grant funded this research. Meilin Haidl, Lauren VanMaurik, Rachel Robins, and Kayla Schmitt provided laboratory assistance. Daniela Delvescovo, Dr. Heather Masonjones and Dr. Abraham Miller provided statistical assistance. Dr. Ann Williams aided in bacterial fouling procedures. Dr. Wayne Price reviewed a draft of the manuscript. Charles Crawford and Bryan Winston at the Florida Fish and Wildlife Commission aided in collection of crabs. Authors are grateful to Dr. Raymond Bauer, Dr. Anson Hines, Dr. Collin McLay, Dr. Tom Miller, and Dr. Victor Kennedy for their insight and experience working with crustaceans gills and blue crabs.

\section{References}

Aguilar, R.; Johnson, E.G.; Hines, A.H.; Kramer, M.A. and Goodison, M.R. 2008. Importance of blue crab life history for stock enhancement and spatial management of the fishery in Chesapeake Bay. Reviews in Fisheries Science, 16: 117-124.

Aldridge, J.B. and Cameron, J.N. 1982. Gill morphometry in the blue crab, Callinectes sapidus Rathbun (Decapoda Brachyura). Crustaceana, 43: 297-305.

Arudpragasam, K. and Naylor, E. 1964. Gill ventilation and the role of reversed respiratory currents in Carcinus maenas (L.). Journal of Experimental Biology, 41: 299-307.

Batang, Z. and Suzuki, H. 1999. Gill-cleaning mechanisms of the mud lobster Thalassina anomala Herbst, 1804 (Decapoda: Thalassinidea: Thalassinidae). Journal of Crustacean Biology, 19: 671-683.

Batang, Z.B. and Suzuki, H. 2000. Gill structure and gill-cleaning mechanisms of the redclaw crayfish Cherax quadricarinatus (Decapoda: Astacidea, Parastacidae). Journal of Crustacean Biology, 20: 699-714.

Batang, Z.B. and Suzuki, H. 2003a. Gill-cleaning mechanisms of the amphibious freshwater crab Geothelphusa dehaani (Decapoda, Brachyura, Potamidae). Journal of Crustacean Biology, 23: 230-240. 
Batang, Z.B. and Suzuki, H. 2003b. Gill cleaning mechanisms of the burrowing thalassinidean shrimps Nihonotryphaea japonica and Upogebia major (Crustacea: Decapoda). Journal of Zoology, 261: 69-77.

Bauer, R.T. 1977. Antifouling adaptations of marine shrimp (Decapoda: Caridea): functional morphology and adaptive significance of antennular preening by the third maxillipeds. Marine Biology, 40: 260-276.

Bauer, R.T. 1978. Antifouling adaptations of marine shrimps (Decapoda: Caridea): functional morphology and adaptive value of general body grooming and antennal cleaning behaviours. Marine Biology, 49: 69-82.

Bauer, R.T. 1981. Grooming behavior and morphology in the decapod Crustacea. Journal of Crustacean Biology, 1: 153-173.

Bauer, R.T. 1987. Stomatopod grooming behavior: functional morphology and amputation experiments in Gonodactylus oerstedii. Journal of Crustacean Biology, 7: 414-432.

Bauer, R.T. 1989. Decapod crustacean grooming: functional morphology, adaptive value, and phylogenetic significance. Crustacean Issues, 6: 49-73.

Bauer, R.T. 1998. Gill-cleaning mechanisms of the crayfish Procambarus clarkii (Astacidea: Cambaridae): experimental testing of setobranch function. Invertebrate Biology, 177: 129-143.

Bauer, R.T. 1999. Gill-cleaning mechanisms of a dendrobranchiate shrimp, Rimapenaeus similis (Decapoda: Penaeidae): description and experimental testing of function. Journal of Morphology, 242: 125-139.

Bauer, R.T. 2004. Remarkable Shrimps: Natural History and Adaptations of the Carideans. Norman, University of Oklahoma Press, 282p.

Bauer, R.T. 2013. Adaptive modification of appendages for grooming (cleaning; antifouling) and reproduction in the Crustacea. p. 337-375. In: M. Thiel and L. Watling (eds), Functional Morphology of Crustacea, Vol. 1. New York, Oxford University Press.

Bert, T.M. 1992. Summary of workshop on current issues related to stone crab (genus Menippe) biology and fisheries. p. 108115. In: T.M. Bert (ed), Proceedings of a symposium on stone crab (genus Menippe) biology and fisheries. Florida Marine Research Publications, Vol. 50.

Bert, T.M.; Warner, R.E. and Kessler, L.D. 1978. The biology and Florida fishery of the stone crab, Menippe mercenaria (Say), with emphasis on southwest Florida. Florida Sea Grant Technical Paper, 9: 1-82.

Bill, R.G. and Thurberg, F.P. 1985. Coughing: A new description of ventilatory reversals produced by the lobster, Homarus americanus. Comparative Biochemistry and Physiology Part A: Physiology, 80: 333-336.

Cake Jr., E.W. 1983. Symbiotic associations involving the southern oyster drill Thais haemastoma floridana (Conrad) and macrocrustaceans in Mississippi waters. Journal of Shellfish Research, 3: 117-128.

Cheung, T.S. 1973. Experiments on simultaneous regeneration of claws in aged male stone crab, Menippe mercenaria (Say), with special reference to terminal molt. Bulletin of the Institute of Zoology Academia Sinica, 12: 1-11.

Churchill, E.P. 1919. Life history of the blue crab (Vol. 870). Govt. print. off..
Clayton, D.H. and Cotgreave, P. 1994. Relationship of bill morphology to grooming behaviour in birds. Animal Behaviour, 47: 195-201.

De Waal, F.B. 1997. The chimpanzee's service economy: food for grooming. Evolution and Human Behavior, 18: 375-386.

Eckstein, R.A. and Hart, B.L. 2000. Grooming and control of fleas in cats. Applied Animal Behaviour Science, 68: 141-150.

Engel, W. 1958. The blue crab and its fishery in Chesapeake Bay. Part 1. Reproduction, early development, growth and migration. Commercial Fisheries Review, 20: 6-17.

Felgenhauer, B.E. 1987. Techniques for preparing crustaceans for scanning electron microscopy. Journal of Crustacean Biology, 7: 71-76.

Felgenhauer, B.E. and Schram, F.R. 1978. Differential epibiont fouling in relation to grooming behaviour in Palaemonetes kadiakensis. Fieldiana: Zoology, 72: 83-100.

Felgenhauer, B.E, and Schram, F.R. 1979. The functional morphology of grooming appendages of Palaemonetes kadiakensis Rathbun, 1902. Fieldiana: Zoology, 2: 1-17.

Gerhart, S.D. and Bert, T.M. 2008. Life-history aspects of stone crabs (genus Menippe): size at maturity, growth, and age. Journal of Crustacean Biology, 28: 252-261.

Gleeson, R.A. 1980. Pheromone communication in the reproductive behavior of the blue crab, Callinectes sapidus. Marine and Freshwater Behaviour and Physiology, 7: 119-134.

Govind, C.K. and Blundon, J.A. 1985. Form and function of the asymmetric chelae in blue crabs with normal and reversed handedness. The Biological Bulletin, 168: 321-331.

Gray, I.E. 1957. A comparative study of the gill area of crabs. The Biological Bulletin, 112: 34-42.

Guillory, V.; Perry, H and Steele, E. 2001. The blue crab fishery of the Gulf of Mexico, United States: A regional management plan. Gulf States Marine Fisheries Commission, 96: 1-301.

Haefner, P. and Shuster, C. 1964. Length increments during terminal molt of the female blue crab, Callinectes sapidus, in different salinity environments. Chesapeake Sciences, 5: 114-118.

Hench, J.; Forward, R.; Carr, S.; Rittschof, D. and Luettich, R. 2004. Testing a selective tidal- stream transport model: Observations of female blue crab (Callinectes sapidus) vertical migration during the spawning season. Limnology and Oceanography, 49: 1857-1870.

Holmquist, J.G. 1985. The grooming behaviour of the terrestrial amphipod Talitroides alluaudi. Journal of Crustacean Biology, 5: 334-340.

Hutchins, M. and Barash, D.P. 1976. Grooming in primates: implications for its utilitarian function. Primates, 17: 145-150.

Jaeger, R.G. 1981. Dear enemy recognition and the costs of aggression between salamanders. The American Naturalist, 117: 962-974.

Jedlicka, J. and Wortham, J.L. 2014. Grooming behaviors in the spider crab Libinia dubia. Florida Scientist, 77: 33-34.

Jivoff, P. and Hines, A.H. 1998. Female behaviour, sexual competition and mate guarding in the blue crab, Callinectes sapidus. Animal Behaviour, 55: 589-603.

Kennedy,V.S. and Cronin, L.E. (eds). 2007. The blue crab: Callinectes sapidus. Maryland Sea Grant College University of Maryland. 
Kinsey, S.T.; Buda, E. and Nordeen, J. 2003. Scaling of metabolic potential in gills of the blue crab, Callinectes sapidus, as a function of salinity. Physiological Biochemistry and Zoology, 76: 105-114.

Kuris, A.M. 1990. A review of patterns and causes of crustacean brood mortality. p. 117-141. In: A. Wenner and A.M. Kuris (eds), Crustacean egg production. Crustacean Issues 7. Rotterdam, A.A. Balkema.

Lipcius, R.; Eggleston, D.; Heck, K.; Seitz, R. and van Montfrans, J. 2007. EPost-settlement abundance, survival, and growth of postlarvae and young juvenile blue crabs in nursery habitats. p. 535-565. In: V.S. Kennedy and L.E. Cronin (eds), The blue crab Callinectes sapidus. Maryland, Maryland Sea Grant College, University of Maryland System, College Park.

Martin, J.W. and Felgenhauer, B.E. 1986. Grooming behaviour and the morphology of grooming appendages in the endemic South American crab genus Aegla (Decapoda, Anomura, Aeglidae). Journal of Zoology, 209: 213-224.

Matsuoka, T. and Suzuki, H. 2011. Setae for gill-cleaning and respiratory-water circulation of ten species of japanese ocypodid crabs. Journal of Crustacean Biology, 31: 9-25.

McLaughlin, P.A. 1982. Comparative morphology of crustacean appendages. The Biology of Crustacea, 2: 197-256.

McLaughlin, P.A. 1983. Internal anatomy. p. 1-52. In: L.H. Mantel (ed), The biology of Crustacea, Vol. 5. Internal Anatomy and Physiological Regulation. New York, Academic Press.

Pearson, W.H. and Olla, B.L. 1977. Chemoreception in the blue crab, Callinectes sapidus. The Biological Bulletin, 153: 346-354.

Pohle, G. 1989. Gill and embryo grooming in lithodid crabs: comparative functional morphology based on Lithodes maja. Crustacean Issues, 6: 75-94.

Powell, Jr E.H. and Gunter, G. 1968. Observations on the stone crab, Menippe mercenaria Say, in the vicinity of Port Aransas, Texas. Gulf and Caribbean Research, 2: 285-299.

Puglisi, M.P. 2008. Smithsonian Marine Station. October 12008. Florida Stone Crabs. Retrieved from http://www.sms.si.edu/ irlspec/Menippe_mercenaria.htm

Ra’Anan, Z. and Sagi, A. 1985. Alternative mating strategies in male morphotypes of the freshwater prawn Macrobrachium rosenbergii (De Man). The Biological Bulletin, 169: 592-601.

Sallem, W.S.; Madkour, F.F. and Wicksten, M.K. 2007. Masking behaviour of the spider crab, Hyastenus hilgendorfi. Crustaceana, 80: 235-245.

Savage, T. 1971. Mating of the stone crab, Menippe Mercenaria (Say) (Decapoda, Brachyura) 1. Crustaceana, 20: 315-316.

Savage, T. and Sullivan, J.R. 1978. Growth and claw regeneration of the stone crab, Menippe mercenaria. St. Petersburg, Florida Department of Natural Resources, Marine Research Laboratory, Florida Marine Research Publications, 32, 77p.

Simonson, J.L. 1985. Reversal of handedness, growth, and claw stridulatory patterns in the stone crab Menippe mercenaria
(Say) (Crustacea: Xanthidae). Journal of Crustacean Biology, 5: 281-293.

Sinclair, M.E. 1977. Agonistic behaviour of the stone crab, Menippe mercenaria (Say). Animal Behaviour, 25: 193-207.

Spruijt, B.M.; Van Hooff, J.A. and Gispen, W.H. 1992. Ethology and neurobiology of grooming behavior. Physiology Review, 72: $825-852$.

Sullivan, J.R. 1979. The stone crab, Menippe mercenaria, in the southwest Florida fishery. St. Petersburg, Florida Department of Natural Resources, Marine Research Laboratory, 81p.

Tankersley, R.A.; Wieber, M.G.; Sigala, M.A. and Kachurak, K.A. 1998. Migratory behavior of ovigerous blue crabs Callinectes sapidus: evidence for selective tidal-stream transport. The Biological Bulletin, 195: 168-173.

VanMaurik, L.N. and Wortham, J.L. 2011. The Grooming Behaviors of the Hawaiian River Shrimp, Macrobrachium grandimanus. Journal of Crustacean Biology, 31: 617-622.

VanMaurik, L.N. and Wortham, J.L. 2014. Grooming as a secondary behavior in the shrimp Macrobrachium rosenbergii (Crustacea, Decapoda, Caridea). ZooKeys, 457: 55.

Ward, H.G. 2012. The blue crab: a survey with application to San Antonio Bay. Austin, Center for Research in Water Resources, 256p.

Warner, G.F. 1977. The biology of crabs. London, Van Nostrand Reinhold Company, 202p.

Wilber, D.H. 1995. Claw regeneration among North Florida stone crabs (genus Menippe) and its implications to the Southwest Florida fishery. Bulletin of Marine Science, 56: 296-302.

Wilber, D.H. and Herrnkind, W.F. 1986. The fall emigration of stone crabs Menippe mercenaria (Say) from an intertidal oyster habitat and temperature's effect on locomotory activity. Journal of Experimental Marine Biology and Ecology, 102: 209-221.

Williams, A.B. 1984. Shrimps, lobsters, and crabs of the Atlantic coast of the eastern United States, Maine to Florida. Washington, Smithsonian Institution Press, 500p.

Wortham, J.L. 2008. Grooming in mantis shrimp. p. 119. In: Society for Integrative and Comparative Biology. Abstract volume 2 from the Annual Meeting in San Antonio, Texas, USA.

Wortham, J.L. and LaVelle, A.D. 2016. Setal morphology of grooming appendages in the spider crab, Libinia dubia. Journal of Morphology, 277: 1045-1061.

Wortham, J.L.; VanMaurik, L.N. and Price, W. 2014. Setal morphology of the grooming appendages of Macrobrachium rosenbergii (Crustacea: Decapoda: Caridea: Palaemonidae) and review of setal classification. Journal of Morphology, 275: 634-649.

Zimmerman, R.; Minello, T.J.; Baumer, T. and Castiglione M. 1989. Oyster reef as habitat for estuarine macrofauna. NOAA Tech. Memo. NMFS-SEFC-249, 16. 